\title{
Female genital mutilation among Iraqi Kurdish women: a cross-sectional study from Erbil city
}

\author{
Berivan A Yasin ${ }^{1}$, Namir G Al-Tawil ${ }^{2}$, Nazar P Shabila ${ }^{2 *}$ and Tariq S Al-Hadithi ${ }^{2}$
}

\begin{abstract}
Background: Iraqi Kurdistan region is one of the areas where female genital mutilation is reportedly widely practiced but inadequately studied. The aim of this study was to determine (i) the prevalence of female genital mutilation among Muslim Kurdish women in Erbil city, (ii) the patterns and types of female genital mutilation, (iii) the factors associated with this practice and (iv) women's knowledge and attitudes towards this practice.

Methods: A cross-sectional study was conducted in the primary health care centers and the Maternity Teaching Hospital in Erbil city, involving 1987 women aged 15-49 years. Data were obtained about female genital mutilation status and knowledge and perception towards this practice. The participants were clinically examined to verify the self-reported female genital mutilation status.
\end{abstract}

Results: The self-reported prevalence of female genital mutilation was $70.3 \%$, while it was $58.6 \%$ according to clinical examination of the women's genitalia. The most common type of female genital mutilation was type I (99.6\%) and the most common age at which mutilation was performed was $4-7$ years (60.2\%). This practice was mostly performed by traditional birth attendants (72.5\%). Only 6.4\% of mutilated women reported having complications after mutilation, most commonly bleeding (3.6\%). The practice was more reported among housewives $(O R=3.3)$, those women whose mothers were mutilated $(O R=15.1)$ or with unknown mutilation status $(O R=7.3)$ and those women whose fathers were illiterate $(O R=1.4)$ or could only read and write $(O R=1.6)$. The common reasons for practicing female genital mutilation were cultural tradition (46.7\%) and dictate of religion (38.9\%). Only 30\% of the participants were aware about the health consequences of female genital mutilation. More than one third (36.6\%) of the women support the practice and 34.5\% have intention to mutilate their daughters.

Conclusions: Prevalence of female genital mutilation among Muslim Kurdish women in Erbil city is very high; although, most cases are of type I. There is clear lack of knowledge about the health consequences of female genital mutilation and a relatively important segment of women support this practice. Custom or tradition and dictate of religion are the main reasons for this practice that need further in-depth exploration.

\section{Background}

\section{Health consequences}

Female genital mutilation (FGM) is associated with a series of health risks and consequences. It often causes pain and bleeding as immediate consequences of the procedure. Other immediate complications include difficulty in passing urine, infection including infection with human immunodeficiency virus, death that can be caused by hemorrhage or infections, unintended labia fusion and psychological consequences. Long term health risks include

\footnotetext{
*Correspondence: nazarshabila@gmail.com

${ }^{2}$ Department of Community Medicine, College of Medicine, Hawler Medical University, Erbil, Iraqi Kurdistan Region, Iraq

Full list of author information is available at the end of the article
}

chronic pain, chronic infections, keloid formation, reproductive tract infections and sexually transmitted infections, increased risk of human immunodeficiency virus infection, poor quality of sexual life, birth complications and psychological consequences. Additional risks for complications particularly from type III include need for later surgery, urinary and menstrual problems, painful sexual intercourse and infertility [1-3].

\section{Violation of human rights}

FGM is a clear violation of human rights of girls and women. It can be considered one of the main manifestations of gender inequality and discrimination related to historical suppression and subjugation of women, denying 
girls and women the full enjoyment of their rights and liberties [4].

\section{Epidemiology}

FGM is a deeply rooted tradition in more than 28 African countries and a few populations in Asia and the Middle East [5]. It is estimated that 100-140 million women have experienced some form of the practice all over the world [6]. It is also estimated that around 3 million girls in sub-Saharan Africa, Egypt and Sudan, the majority of which below 15 years, are at risk of genital mutilation annually [5].

\section{Classification of FGM}

The World Health Organization has classified the forms of FGM into four types. Type I, which is the mildest type, involves partial or total removal of the clitoris and/ or the prepuce. Type I mutilation is subdivided into Type Ia, removal of the clitoral hood or prepuce only and Type Ib, removal of the clitoris with the prepuce. Type II involves partial or total removal of the clitoris and the labia minora, with or without excision of the labia majora. There are three major variations of type II mutilation; Type IIa involves removal of the labia minora only, Type IIb involves partial or total removal of the clitoris and the labia minora and Type IIc involves partial or total removal of the clitoris, the labia minora and the labia majora. Type III, the most severe type, involves narrowing of the vaginal orifice with creation of a covering seal by cutting and appositioning the labia minora and/or the labia majora, with or without excision of the clitoris (infibulation). Type III includes two subdivisions; Type IIIa involves removal and apposition of the labia minora and Type IIIb involves removal and apposition of the labia majora. Type IV involves all other harmful procedures to the female genitalia for non-medical purposes, for example: pricking, piercing, incising, scraping and cauterization [1].

In classifying FGM, the word 'clitoris' is used to refer to the clitoral glans (i.e. the external part of the clitoris). It does not include the clitoral body or the crura, which are situated directly beneath the soft tissue and are not visible from outside. The clitoral prepuce is the fold of skin that surrounds and protects the clitoral glans [1].

\section{Legislations against FGM}

Legislations prohibiting and criminalizing FGM have been introduced in several countries where FGM is practiced including several African countries [7]. Most industrialized countries, including the majority of Western Europe countries, where immigrant communities continue the practice have either employed already existing general criminal law provisions related to abuse or mutilation or introduced specific criminal law provisions prohibiting FGM $[5,8]$.

\section{FGM in Iraqi Kurdistan region}

FGM is widely practiced in Iraqi Kurdistan region, which is inhabited mostly by Muslim Kurds. According to activists and human rights organizations, the prevalence of FGM in Iraqi Kurdistan region is around 40\% [9]. The roots of the practice in Kurdistan region are unclear. Although the practice is common in Iraqi and Iranian Kurdish areas [10], it is less common in other parts of Iraq and in Kurdish areas in neighboring Turkey. The prevalence of FGM is particularly high in the rural areas of Iraqi Kurdistan region. In some specific rural areas a prevalence of up to $70 \%$ has been reported. Traditionally, Kurdish society is agrarian; a significant part of the population lives outside cities, where the high prevalence of illiteracy and poverty and presence of conservative Islam appear to play a role in the high prevalence of FGM $[9,11,12]$.

\section{Study objectives}

There is little published evidence that has quantified the problem of FGM in Kurdistan region and described its patterns and associated factors. Moreover, there is lack of demographic and health survey data on Kurdish community and Iraq as whole. Therefore, this study was conducted to determine (i) the prevalence of FGM among Kurdish women in Erbil city, (ii) the patterns and types of FGM, (iii) the factors associated with this practice and (iv) women's knowledge and attitudes towards this practice.

\section{Methods}

\section{Setting and design}

A cross-sectional study was conducted in Erbil city, the capital of Kurdistan region of Iraq, from November 2007 to March 2009. The study was carried out in the delivery rooms of the Maternity Teaching Hospital and the maternal care units of 14 primary health care centers in Erbil city.

\section{Study participants}

A sample size of 1860 women was calculated based on having a \pm 3 precision around an estimated prevalence of FGM of $50 \%$ with a $95 \%$ confidence interval. The sample size was increased to 2000 to adjust for possible nonresponse. The study participants included married and unmarried Muslim Kurdish women of childbearing age (15-49 years). A convenience sample of 2000 women attending the primary health care centers and the delivery rooms of Erbil Maternity Teaching Hospital was selected. From each of the 14 primary health care centers in Erbil city, around 70 women were invited to participate 
in the study regardless of the catchment area of the health center. At the delivery rooms of Erbil Maternity Teaching Hospital, 1000 women were invited to participate in the study. Participants' selection was made arbitrarily before knowing their FGM status.

\section{Data collection}

Data were collected using a structured intervieweradministered questionnaire. The questionnaire addressed the main sociodemographic characteristics of the participants and the self-reported circumcision status of the participants and their mothers. The questionnaire also addressed the knowledge and attitude of the participants towards FGM. Here we used open questions to encourage participants to talk about FGM in terms of the reasons for practicing it, the known potential health consequences, whether they support this practice or not and whether they intend to mutilate their daughters or not. A female doctor verified the self-reported circumcision status of participants by clinical examination. Verbal informed consent was obtained from each participant prior to study enrollment. The study was approved by the Research Ethics Committee of Hawler Medical University.

\section{Data analysis}

The statistical package for social sciences (SPSS, version 18) was used for statistical analysis. Proportions, means and tables were used for data summarization and presentation. Student's t-test was used for comparing means. Univariate logistic regression was performed for assessing the association of sociodemographic factors with the practice of FGM. Multiple logistic regression for controlling for associated sociodemographic factors was performed for those variables that were statistically significant in the univariate logistic model. Degree of association was measured by odds ratio with $95 \%$ confidence interval. A p-value of $\leq 0.05$ was considered as statistically significant.

\section{Results}

Of the 2000 women, 1987 agreed to participate in the study with a response rate of $99.4 \%$. The mean age \pm SD of the participants was $27.6 \pm 6.9$ years (range 15-49). Other sociodemographic characteristics of the participants are shown in Table 1.

Of the 1987 participants, 1397 (70.3\%) reported to have undergone FGM. Clinical examination verified presence of FGM among 1164 (58.6\%) participants. The mean age \pm SD of clinically confirmed mutilated participants $(27.8 \pm 7.0$ years $)$ was significantly higher $(P=0.050)$ than that of non-mutilated $(27.2 \pm 6.9)$. Majority had type I mutilation (99.6\%). Only five participants had type II mutilation; two were at the age of 15-19 years and three at the age of 20-29 years, all of them were born in rural
Table 1 Sociodemographic characteristics of the participants

\begin{tabular}{|c|c|c|}
\hline Characteristic & No. & (\%) \\
\hline \multicolumn{3}{|l|}{ Age group (years) } \\
\hline $15-19$ & 193 & (9.7) \\
\hline $20-29$ & 1098 & $(54.9)$ \\
\hline $30-39$ & 567 & $(28.4)$ \\
\hline $40-49$ & 142 & $(7.1)$ \\
\hline \multicolumn{3}{|l|}{ Marital status } \\
\hline Married & 1882 & $(94.7)$ \\
\hline Single & 95 & (4.8) \\
\hline Widowed & 10 & (0.5) \\
\hline \multicolumn{3}{|l|}{ Occupation } \\
\hline Housewife & 1606 & $(80.8)$ \\
\hline Employed (public or private sectors) & 315 & $(15.9)$ \\
\hline Student & 66 & (3.3) \\
\hline \multicolumn{3}{|l|}{ Place of birth } \\
\hline Urban & 1492 & $(75.1)$ \\
\hline Rural & 495 & $(24.9)$ \\
\hline \multicolumn{3}{|l|}{ Mother education } \\
\hline Illiterate & 1617 & $(81.4)$ \\
\hline Read and write & 89 & (4.5) \\
\hline Primary school & 164 & (8.3) \\
\hline Intermediate school and higher education & 117 & (5.9) \\
\hline \multicolumn{3}{|l|}{ Father education } \\
\hline Illiterate & 1002 & $(50.4)$ \\
\hline Read and write & 146 & (7.3) \\
\hline Primary school & 431 & $(21.7)$ \\
\hline Intermediate and higher school & 408 & $(20.5)$ \\
\hline
\end{tabular}

areas, the mothers of four of them were illiterate and the father of one of them was illiterate. Only 983 (84.5\%) mutilated participants remembered who performed mutilation for them. Of these, the majority of FGMs (72.5\%) were performed by traditional birth attendants. Only 747 (64.2\%) mutilated participants remembered the age at which they were mutilated. Of these, the majority (60.2\%) were mutilated when they were between the ages of four and seven years. Around $6.4 \%$ of mutilated participants reported complications after mutilation; most commonly in the form of bleeding (3.6\%). Details of the FGM characteristics of the clinically verified mutilated participants are shown in Table 2.

The practice of FGM was significantly associated with the employment status of the women, FGM status of their mothers and education status of their fathers. The practice was more reported among housewives (adjusted OR $=3.3$, 95\% confidence interval (CI) 1.8-6.1), those women whose mothers were mutilated (adjusted $\mathrm{OR}=15.1$, 
Table 2 Genital mutilation characteristics of clinically verified mutilated participants $(n=1164)$

\begin{tabular}{|c|c|c|}
\hline Characteristic & No. & (\%) \\
\hline \multicolumn{3}{|l|}{ Type of FGM $(n=1164)$} \\
\hline Type I* & 1159 & $(99.6)$ \\
\hline Type $\|^{* *}$ & 5 & $(0.4)$ \\
\hline \multicolumn{3}{|c|}{ Person performed mutilation $(n=983)$} \\
\hline Traditional birth attendant & 713 & $(72.5)$ \\
\hline Traditional circumciser & 119 & $(12.1)$ \\
\hline Relative & 109 & $(11.1)$ \\
\hline Neighbor & 33 & (3.4) \\
\hline Health care providers & 9 & $(0.9)$ \\
\hline \multicolumn{3}{|c|}{ Age at mutilation (years) $(n=747)$} \\
\hline$<4$ & 124 & $(16.6)$ \\
\hline $4-7$ & 450 & $(60.2)$ \\
\hline $8-11$ & 158 & $(21.2)$ \\
\hline $12-15$ & 14 & (1.9) \\
\hline$\geq 16$ & 1 & $(0.1)$ \\
\hline \multicolumn{3}{|c|}{ Complications after FGM $(n=1164)$} \\
\hline \multicolumn{3}{|l|}{ Short-term complications } \\
\hline Bleeding & 42 & (3.6) \\
\hline Pain & 11 & $(0.9)$ \\
\hline \multicolumn{3}{|l|}{ Long-term complications } \\
\hline Reduced libido & 20 & (1.7) \\
\hline Psychological & 2 & $(0.2)$ \\
\hline No complications & 1089 & (93.6) \\
\hline
\end{tabular}

95\% CI 10.6-21.6) or with unknown mutilation status (adjusted OR $=7.3,95 \%$ CI 4.4-12.0) and those women whose fathers were illiterate (adjusted OR $=1.4,95 \% \mathrm{CI}$ 1.1-1.9) or could only read and write (adjusted OR = 1.6, 95\% CI 1.02-2.5). No statistically significant association was found between the practice of FGM and the place of birth of the women or the education status of their mothers. Details of logistic regression for factors associated with the practice of FGM are shown in Table 3.

Only $29.5 \%$ of participants were aware that FGM could cause some complications. These participants identified reduced libido and bleeding as the most common complications; $23.9 \%$ and $3.6 \%$, respectively. The participants cited social and cultural tradition (46.7\%) and dictate of religion (38.8\%) as the primary reasons for practicing FGM. More than one third (36.6\%) of the women support the practice. Around 35\% of participants have the intention to mutilate their daughters; $46.8 \%$ of mutilated participants and $17.1 \%$ of non-mutilated participants. Details of participants' perception about FGM are shown in Table 4.

\section{Discussion}

FGM is a deeply rooted tradition that is still practiced in Erbil city. Cultural tradition and dictate of religion are the main provocative factors for continuation of the practice. According to UNICEF, Iraqi Kurdistan region and the Kurdish area of Iran have intermediate prevalence of FGM [4]. The high prevalence of FGM reported in this study was relatively lower than those reported by other studies from similar settings in Iraqi Kurdistan region; $63.0-72.8 \%$ in Erbil governorate [9,13], 73.0-77.9\% in Sulaimania governorate $[9,14]$ and $65.0-81.2 \%$ in Garmian and New Kirkuk region $[9,15]$. However, the reported rate of this study was in agreement with a study from Iranian Kurdish area in 2011 (55.7\%) [10]. The above-mentioned studies from Iraqi Kurdistan region have primarily relied on self-declared FGM status in interviews, to determine the prevalence of FGM.

The relatively lower rate reported in this study might be attributed to verification of FGM by clinical examination rather than depending merely on interview results. A relatively high proportion of participants in this study (11.7\%) reported that they have been mutilated but clinical examination revealed no mutilation. This does not necessarily mean that these women are not telling the truth. Under-reporting FGM is far more common than over-reporting $[1,16]$. In some societies women are expected to deny or under-report the type of FGM rather than over-reporting it. However, in other societies women might claim they are mutilated because of the high social pressure and the risk of social ostracism [17]. The disagreement between self-reporting and clinical examination can also be attributed either to having a very small cutting that could have been disappeared with anatomical growth of genital area or having made a small wound which was regarded as circumcision [18]. Disagreement between reporting FGM and examination findings has also been shown in a study from Egypt where $5 \%$ of women reported that they had been mutilated but were found not to have any evidence of FGM on examination. On the other hand, $1 \%$ of women had reported that they were not circumcised but some evidences of FGM were found on examination [19].

The reports of high prevalence of FGM in Iraqi Kurdistan region in 2007 resulted in launching the campaign of "Stop FGM in Kurdistan" by a number of civil society organizations and women's rights groups. This awareness and advocacy campaign that was supported by a number of regional parliament members helped in adopting legal prohibition of FGM in Kurdistan region [20]. The substantial efforts that have been made in Kurdistan region to 
Table 3 Logistic regression for factors associated with the practice of FGM among participants

\begin{tabular}{|c|c|c|c|c|c|c|c|c|}
\hline \multirow[t]{3}{*}{ Characteristic } & \multicolumn{4}{|c|}{ FGM status of women } & \multicolumn{2}{|c|}{ Crude } & \multicolumn{2}{|c|}{ Adjusted* } \\
\hline & \multicolumn{2}{|c|}{ Mutilated } & \multicolumn{2}{|c|}{ Non-mutilated } & \multirow{2}{*}{$\begin{array}{l}\text { Odds ratio } \\
(95 \% \mathrm{Cl})\end{array}$} & \multirow[t]{2}{*}{$P$ value } & \multirow{2}{*}{$\begin{array}{c}\text { Odds ratio } \\
(95 \% \mathrm{Cl})\end{array}$} & \multirow[t]{2}{*}{$P$ value } \\
\hline & No. & (\%) & No. & (\%) & & & & \\
\hline \multicolumn{9}{|l|}{ Age group (years) } \\
\hline $15-24$ & 338 & $(43.7)$ & 435 & $(56.3)$ & $0.8(0.6-1.0)$ & 0.510 & & \\
\hline $25-34$ & 339 & $(41.0)$ & 488 & $(59.0)$ & $0.9(0.7-1.1)$ & 0.279 & & \\
\hline$\geq 35$ & 146 & $(37.7)$ & 241 & $(62.3)$ & & & & \\
\hline \multicolumn{9}{|l|}{ Occupation } \\
\hline Housewife & 1024 & $(63.8)$ & 582 & $(36.2)$ & $4.7(2.7-8.1)$ & $<0.001$ & $3.3(1.8-6.1)$ & $<0.001$ \\
\hline Employed & 122 & $(38.7)$ & 193 & (61.3) & $1.7(0.9-3.0)$ & 0.081 & $1.8(0.9-3.5)$ & 0.075 \\
\hline Student & 18 & $(27.3)$ & 48 & $(72.7)$ & & & & \\
\hline \multicolumn{9}{|l|}{ Place of birth } \\
\hline Rural & 315 & $(63.6)$ & 180 & (36.4) & $1.3(1.1-1.6)$ & 0.009 & $1.0(0.8-1.2)$ & 0.702 \\
\hline Urban & 849 & $(56.9)$ & 643 & $(43.1)$ & & & & \\
\hline \multicolumn{9}{|l|}{ Mother FGM status } \\
\hline Mutilated & 1067 & $(70.2)$ & 453 & $(29.8)$ & $18.5(13.1-26.2)$ & $<0.001$ & $15.1(10.6-21.6)$ & $<0.001$ \\
\hline Don't know & 57 & $(50.9)$ & 55 & $(49.1)$ & $8.2(4.9-13.4)$ & $<0.001$ & $7.3(4.4-12.0)$ & $<0.001$ \\
\hline Not mutilated & 40 & $(11.3)$ & 315 & $(88.7)$ & & & & \\
\hline \multicolumn{9}{|l|}{ Mother education } \\
\hline Illiterate & 1015 & $(62.8)$ & 602 & $(37.2)$ & $5.1(3.3-7.9)$ & $<0.001$ & $1.5(0.9-2.6)$ & 0.142 \\
\hline Read and write & 45 & $(50.6)$ & 44 & $(49.4)$ & $3.1(1.7-5.6)$ & $<0.001$ & $1.4(0.7-2.8)$ & 0.344 \\
\hline Primary school & 75 & $(45.7)$ & 89 & $(54.3)$ & $2.6(1.5-4.3)$ & $<0.001$ & $1.3(0.7-2.5)$ & 0.389 \\
\hline Intermediate school and higher education & 29 & $(24.8)$ & 88 & $(75.2)$ & & & & \\
\hline \multicolumn{9}{|l|}{ Father education } \\
\hline Illiterate & 654 & $(65.3)$ & 348 & $(34.7)$ & $2.7(2.1-3.4)$ & $<0.001$ & $1.4(1.1-1.9)$ & 0.022 \\
\hline Read and write & 96 & $(65.8)$ & 50 & $(34.2)$ & $2.7(1.8-4.1)$ & $<0.001$ & $1.6(1.02-2.5)$ & 0.040 \\
\hline Primary school & 246 & $(57.1)$ & 185 & $(42.9)$ & $1.9(1.4-2.5)$ & $<0.001$ & $1.3(0.9-1.8)$ & 0.110 \\
\hline Intermediate school and higher education & 168 & $(41.2)$ & 240 & $(58.8)$ & & & & \\
\hline
\end{tabular}

Cl confidence interval, FGM female genital mutilation.

* Only those variables that were significant in the univariate logistic model were considered for the multiple logistic regression model.

abandon this practice of FGM since 2007 resulted in passing the Family Violence Bill in June 2011. This bill includes several provisions criminalizing FGM in Kurdistan. The regional government also established the Women's Affairs Supreme Council, a governmental agency directly linked to the Prime Minister's office and responsible to combat all types of gender-based violence including FGM. These efforts have actively engaged civil society organizations and religious leaders to help in reducing the practice of FGM. These initiatives might have contributed to the increased awareness of the new generation about the health risks of FGM, which is evident from having a considerable proportion of the mutilated participants not having the intension to mutilate their daughters and the marginally statistically significant lower mean age of non-mutilated study participants than that of mutilated participants.
Broadly speaking, there is some evidence of increased awareness of the new generation about the health risks of FGM. In Egypt, the attitude about circumcision appears to be changing as the proportion of evermarried women who believe that circumcision should continue has dropped from 82 percent in 1995 to 63 percent in 2008 [21]. In Nigeria, similarly women younger than 36 years had more awareness about health risks of FGM than older women [22]. Moreover, women after marriage might change their attitudes towards FGM by following the customs of their husbands' families that might not practice FGM in their tradition.

The main reasons for practicing FGM in this study were social and cultural tradition and dictate of religion. Moreover, a considerable number of study participants supported continuation of FGM practice, in particular the mutilated participants. This suggests that the main 
Table 4 Knowledge and perception of participants about FGM $(n=1987)$

\begin{tabular}{|c|c|c|}
\hline Variable & No. & (\%) \\
\hline \multicolumn{3}{|l|}{ Impact of FGM on woman's health } \\
\hline No & 1033 & (52.0) \\
\hline Don't know & 368 & (18.5) \\
\hline Yes & 586 & $(29.5)$ \\
\hline Reduce libido & 474 & $(23.9)$ \\
\hline Bleeding & 71 & (3.6) \\
\hline Pain & 26 & (1.3) \\
\hline Infertility & 4 & $(0.2)$ \\
\hline Gloominess & 3 & $(0.2)$ \\
\hline Others (infection, difficult labor, etc.) & 8 & $(0.4)$ \\
\hline \multicolumn{3}{|l|}{ Reasons for practicing FGM } \\
\hline Social and cultural tradition & 928 & $(46.7)$ \\
\hline Dictate of religion & 770 & $(38.8)$ \\
\hline Reduce libido & 155 & $(7.8)$ \\
\hline Cleanliness & 14 & $(0.7)$ \\
\hline Remove bad odor & 7 & $(0.4)$ \\
\hline More beautiful appearance & 5 & $(0.3)$ \\
\hline Don't know & 107 & $(5.4)$ \\
\hline \multicolumn{3}{|l|}{ Attitude towards FGM } \\
\hline Support FGM & 728 & (36.6) \\
\hline Against FGM & 1259 & $(63.4)$ \\
\hline Intention to mutilate daughters & 686 & (34.5) \\
\hline Mutilated women $(n=1164)$ & 545 & $(46.8)$ \\
\hline Non-mutilated women $(n=823)$ & 141 & (17.1) \\
\hline
\end{tabular}

provocative factor for continuation of the practice is tradition and customs inherited in the family from mothers to daughters. In Egypt, which shares a relatively similar socio-cultural context to Iraq and Kurdistan region, the main reported reasons behind the practice are religious tradition (33.4\%), cultural and social tradition (17.9\%) and chastity (15.9\%) [23]. Though no religious scripts prescribe FGM, it is often believed that the practice has religious support [23-25]. Religious leaders take varying positions with regard to FGM: some promote it, some consider it irrelevant to religion, and others contribute to its elimination [26]. For example, a reputed Islamic scholar in Iraqi Kurdistan region condemned the practice and completely denied any association between FGM and Islam [24]. As FGM is frequently linked to religious dictate, there should be an emphasis on the role played by religious leaders in fighting this phenomenon. In fact, the role of religious leaders in combating FGM in the region is extremely important due to the respect and influence they have in the local communities.
The most common type of FGM in this study was type I. In Egypt, type I and II are the most commonly reported types of FGM while in Africa type II accounts for up to $80 \%$ of all cases [23]. Studies that are based on clinical examination have documented large variations in the level of agreement between self-reported descriptions and clinically observed types of FGM [16,27-30]. Both under-reporting and less commonly over-reporting have been documented. The commonest discrepancy is that a large percentage of women declare that they have undergone Type I or II, even though clinical examination indicates Type III [30]. In addition, the reliability of clinical observation can be limited by natural anatomical variations and difficulty in estimating the amount of clitoral tissue under an infibulation [1].

In this study most of mutilations were carried out by traditional birth attendants, and a limited proportion by traditional circumcisers and health care providers. Unlike male traditional circumcisers for male circumcision that widely exist in the Iraqi Kurdish society, female traditional circumcisers rarely exist. Therefore, the traditional birth attendants, who usually have many duties besides attending deliveries of women at home, might consider genital mutilation one of their duties either as a religious obligation or as a custom to be practiced in their communities. According to different settings, different professions are involved in FGM. Unlike the Iraqi Kurdistan region, traditional circumcisers are responsible for performing most of the FGMs in the Iranian Kurdish area although the two areas share similar socio-cultural and religious contexts. Similarly, in Nigeria mutilation is mostly carried out by traditional circumcisers $[10,31]$. In other settings like Egypt, FGM is mostly performed by physicians [22,23]. According to the global strategy to stop health care providers from performing FGM, health care provider are responsible for performing more than $18 \%$ of all FGMs. In 2008, the World Health Assembly adopted a resolution on the elimination of FGM, in which all member states agreed to work towards the abandonment of FGM, including ensuring the procedure is not performed by health professionals [32]. However, health professionals continue to perform FGM in many settings [1]. In Erbil, the role of health care providers in performing FGM $(0.9 \%)$ is much lower than other countries like Egypt (24-67\%) [21,23] and Nigeria (11.9\%) [33].

The age at which girls are mutilated varies among countries, ethnic groups and even regions within the same country $[2,23]$. Most participants in this study were mutilated when they were between the ages of four and seven years; a finding that agrees with a study from the Iranian Kurdish area where $54 \%$ of participants had the practice when they were below the age of seven years [10]. Another study from Sulaimania governorate reported an older age 
group (6-11 years) as the most common age of mutilation (60\%) [14]. A study from Nigeria showed that $85 \%$ of women were mutilated when they were below one year [34] while in Egypt the mean age of the time of FGM is 10.1 years [23].

The extent of genital tissue cutting generally increases from Type I to III and the severity and risks are closely related to the anatomical extent of the cutting [1]. Therefore, the evidently low rate of complications reported in this study may be attributed to the high proportion of type I mutilation. The low complication rate could also be attributed to the fact that a relatively high proportion of women (35.8\%) did not remember the event and reported no complications or that women do not link the complications to FGM due to their poor knowledge. Although reduced libido was reported as a complication of FGM, this could have other reasons than FGM such as marital status, depression and gynecologic problems. Unfortunately, this study did not investigate other possible causes of the reported reduced libido.

The practice of FGM was significantly associated with the mutilation status of the mother. Such a finding indicates that FGM is a custom that runs in the family as continuous practice from mothers to daughters. In a study in Indonesia from 2003, the majority of mothers of a sample of mutilated women reported themselves as being mutilated [35].

It is generally agreed that women's education may contribute to a reduction of the practice [2]. Several other studies have reported a negative association between FGM and the education level of mothers $[4,10,19,23]$. However, this study did not show statistically significant association between FGM and the education status of the mother. Such findings might suggest that education alone is not sufficient to lead to the abandonment of FGM and might signal the superiority of traditions, cultural inherits and religious dictate over education in the Kurdish society. Interestingly, this study showed a statistically significant association between FGM and the education status of the father, which agrees with a study from Egypt [23]. This may reflect the decision making process on FGM in the family and the society and the potential power of the father in making such decision. The role of father in making such decisions has not been studied in the Kurdish society so far. This issue needs further exploration and the potentially effective role of father should be considered in prevention programs. Research from other settings like Gambia has shown that the decision making for undergoing FGM is in large part made by mothers. However, there are instances where it is a joint decision by both mother and father with the latter only informed to obtain his agreement. Other decision-makers are female members in the family, particularly grandmothers [36].

\section{Study limitations}

This study was not able to identify and report the exact sub-types of FGM among the participants. It also does not cover the rural areas where a higher prevalence of FGM is expected. Future research should focus on the prevalence of the complications associated with FGM and the exploration of the roots of FGM in the Kurdish community in an in-depth manner.

\section{Conclusions}

Prevalence of FGM in Erbil city is very high; however, most cases are of type I. The practice is significantly associated with the employment status of the women, FGM status of their mothers and education status of their fathers. There is clear lack of knowledge about the health consequences of FGM. There is still a relatively important segment of women who support FGM and intend to mutilate their daughters. This signals the need for extensive education programs that could be carried out by health and education authorities in addition to religious leaders. Custom or tradition and dictate of religion are the main reasons for FGM that need further in-depth exploration.

\section{Abbreviations}

Cl: Confidence interval; FGM: Female genital mutilation.

\section{Competing interests}

The authors declare that they have no competing interests.

\section{Authors' contributions}

BAY and NGAT conceptualized the study. BAY, NGAT and TSAH participated in designing the study. BAY, NGAT and NPS collected the data and carried out data analysis. BAY and NPS drafted and finalized the manuscript. TSAH and NGAT extensively reviewed and edited the manuscript. All authors contributed to interpreting study results and writing the manuscript. All authors read and approved the final manuscript.

\section{Acknowledgement}

The authors would like to thank the staff in the primary health care centers and the Maternity Teaching Hospital for their cooperation and support and the women who participated in the study.

\section{Author details}

${ }^{1}$ General Directorate of Health, Erbil, Iraqi Kurdistan Region, Iraq ${ }^{2}$ Department of Community Medicine, College of Medicine, Hawler Medical University, Erbil, Iraqi Kurdistan Region, Iraq.

Received: 29 September 2012 Accepted: 6 September 2013 Published: 8 September 2013

\section{References}

1. OHCHR, UNAIDS, UNDP, UNECA, UNESCO, UNFPA, UNHCR, UNICEF, UNIFEM, WHO: Eliminating Female Genital Mutilation: An Interagency Statement. Geneva: WHO; 2008.

2. UNICEF: Changing A Harmful Social Convention, Female Genital Mutilation/ Cutting. Italy: Innocenti digest; 2005.

3. WHO: A Systematic Review of the Health Complications of Female Genital Mutilation Including Sequel in Childbirth. Geneva: WHO; 2000.

4. UNICEF: Female Genital Mutilation/Cutting: A Statistical Exploration. New York: UNICEF; 2005 .

5. WHO: Female genital mutilation-new knowledge spurs optimism. Progress in Sexual and Reproductive Health Research 2006, 72:1. 
6. WHO: Female Genital Mutilation, Integrating the Prevention and The Management of the Health Complications Into the Curricula of Nursing and Midwifery: A teacher's Guide. Geneva: WHO; 2001.

7. Center for Reproductive Rights: Female Genital Mutilation (FGM): Legal Prohibitions Worldwide. New York: Center for Reproductive Rights; 2008.

8. Poldermans S: Combating Female Genital Mutilation in Europe: A Comparative Analysis of Legislative and Preventative Tools in the Netherlands, France, the United Kingdom, and Austria, MSc thesis. Vienna: University of Vienna; 2006.

9. WADI: Female Genital Mutilation in Iraqi-Kurdistan: An Empirical Study by WADI. Frankfurt: WADI; 2010.

10. Pashaei T, Rahimi A, Ardalan A, Felah A, Majlessi F: Related factors of female genital mutilation (FGM) in Ravansar (Iran). J Women's Health Care 2012, 1:108.

11. Markey P: Fighting Female Genital Mutilation FGM in Iragi Kurdistan, One Kurdish Village At A Time. http://www.ekurd.net/mismas/articles/misc2012/ 10/state6569.htm.

12. von der Osten-Sacken T, Uwer T: Is female genital mutilation an Islamic problem? Middle East Quarterly 2007, 14(1):29-36.

13. Muhammed-Taher HH: Prevalence Of and Factors Associated With Violence Among A Group of Married Women in Erbil, MSc thesis. Erbil: Hawler Medical University, College of Medicine; 2011.

14. Muhammad KP: Prevalence of FGM Among Women Attending Karaza Wishik Health Center, MSc thesis. Sulaimania: University of Sulaimania; 2006.

15. The Campaign Against Female Genital Mutilation. http://en.wadi-online.de/ index.php?option=com content\&view=article\&id=70\&ltemid $=18$.

16. Snow RC, Slanger TE, Okonofua FE, Oronsaye F, Wacker J: Female genital cutting in southern urban and peri-urban Nigeria: self-reported validity, social determinants and secular decline. Trop Med Int Health 2002, 7:91-100.

17. UNICEF: Legislative Reform to Support the Abandonment of Female Genital Mutilation/Cutting. New York: UNICEF; 2010.

18. Kolucki B: Female genital mutilation: disabling women and disabling society. http://www.disabilityworld.org/01-03_04/women/fgm.shtml.

19. Egyptian Fertility Care Society: Clinic-Based Investigation of Typology and SelfReporting of FGM in Egypt. Cairo: The Population Council; 1996.

20. Stop Violence Against Women: New law criminalizing female circumcision in Iraq. http://www.stopvaw.org/New_Law_Criminalizing_Female_Genital_ Mutilation in Iraq.html.

21. El-Zanaty F, Way A: Egypt Demographic and Health Survey 2008. Cairo, Egypt: Ministry of Health; 2009.

22. Okhiai O, Idonije OB, Asika EC: Awareness of health risks of female genital mutilation among women of child bearing age in two rural communities in Nigeria. Asian Journal of Medical Sciences 2011, 3(6):223-227.

23. Tag-Eldin M, Gadalla M, Altayeb N: Prevalence of female genital mutilation among Egyptian girls. Bull World Health Org 2008, 86:241-320.

24. Al-Zalmi Ml: [Female Genital Mutilation: Side Effects and Its Banning in Quran]. Erbil: Shahab Press; 2011. Arabic.

25. Foundation for Women's Health, Research and Development (FORWARD): Female Genital Mutilation: Information Pack; 2002. http://www.forwarduk.org. uk/downloads/FORWARD_FGM_information_pack.pdf.

26. WHO: Female Genital Mutilation Fact Sheet; 2012. http://www.who.int/ mediacentre/factsheets/fs241/en/

27. Morison L, Scherf C, Ekpo G, Paine K, West B, Coleman R, Walraven G: The long-term reproductive health consequences of female genital cutting in rural Gambia: a community-based survey. Trop Med Int Health 2001 6:643-653

28. Msuya SE, Mbizvo E, Hussain A, Sundby J, Sam NE, Stray-Pedersen B: Female genital cutting in Kilimanjaro, Tanzania: changing attitudes? Trop Med Int Health 2002, 7:159-165.

29. Klouman E, Manongi R, Klepp Kl: Self-reported and observed female genital cutting in rural Tanzania: associated demographic factors, HIV and sexually transmitted infections. Trop Med Int Health 2005, 10:105-115.

30. Elmusharaf S, Elhadi N, Almroth L: Reliability of self reported form of female genital mutilation and WHO classification: cross sectional study. BMJ 2006, 333(7559):124.

31. UNICEF: Nigeria: Female Genital Mutilation. Nigeria: UNICEF; 2003.

32. WHO: Global Strategy to Stop Health-care Providers from Performing Female Genital Mutilation. Geneva: WHO; 2010

33. Mandara MU: Female genital mutilation in Nigeria. Int J Gynecol Obstet 2004, 84(3):291-298.
34. National Population Commission (NPC) [Nigeria] and ORC Macro: Nigeria Demographic and Health Survey 2003. National Population Commission and ORC Macro: Calverton, Maryland; 2004.

35. Budiharsana M, Amaliah L, Utomo B: Erwinia: Female Circumcision in Indonesia, Extent, Implications and Possible Interventions to Uphold Women's Health Rights. Jakarta: Population Council and USAID; 2003.

36. Koroma JM: Female Genital Mutilation in the Gambia: A Desk Review. Banjul, Gambia: National Women's Bureau; 2002.

doi:10.1186/1471-2458-13-809

Cite this article as: Yasin et al:: Female genital mutilation among Iraq Kurdish women: a cross-sectional study from Erbil city. BMC Public Health 2013 13:809.

\section{Submit your next manuscript to BioMed Central and take full advantage of:}

- Convenient online submission

- Thorough peer review

- No space constraints or color figure charges

- Immediate publication on acceptance

- Inclusion in PubMed, CAS, Scopus and Google Scholar

- Research which is freely available for redistribution

Submit your manuscript at www.biomedcentral.com/submit 